\title{
Profits and social performance of small-scale fishing in the Upper Paraná River floodplain (Brazil)
}

\author{
Carvalho, AR.* \\ Laboratório de Biodiversidade do Cerrado, Universidade Estadual de Goiás, \\ BR 153, Jardim Arco Verde, CP 459, CEP 75074-840, Anápolis, GO, Brazil \\ *e-mail: a_r_carvalho@yahoo.com.br
}

Received March 30, 2006 - Accepted June 6, 2006 - Distributed February 29, 2008

(With 1 figure)

\begin{abstract}
Small scale fishing profits in two communities in the Upper Paraná River floodplain (Porto Rico - PRI and Porto São José - PSJ villages) are assessed based on interviews carried out with professional fishermen. There is a high illiteracy level in both PRI (50\%) and PSJ (44.5\%). The main contributions to income are "vessel costs" and "fish consumption" by the family. Specific tackle (such as cevadeira) and gear used for fishing close to dams make the gear costs higher at PSJ, emphasising the heterogeneity of the activity. The majority of fishermen in both villages have income complementation activities associated with tourism, because floodplain fishing is not a profitable occupation with any poverty alleviation capacity. Since the ecosystem is seriously disrupted, nowadays fishers are vulnerable to high oscillations in costs and income due to uncertainty in catches aggravated by flood control of the dams.
\end{abstract}

Keywords: artisanal fishing, Upper Paraná River, floodplain, hydroelectric dams, small-scale fishing.

\section{Aspectos financeiros e status social da pesca de pequena escala da planície de inundação do Alto Rio Paraná}

\begin{abstract}
Resumo
A renda da pesca de pequena escala em duas comunidades na planície de inundação do Alto Rio Paraná (Porto Rico PRI e Porto São José - PSJ) foi calculada a partir de informações com os pescadores profissionais. Há alto analfabetismo em PRI (50\%) e PSJ (44,5\%). Os itens que mais contribuem com a formação da renda são "custos com a embarcação" e "consumo do pescado pela família". Estratégias e tralhas específicas (como a cevadeira) são usadas para pescar perto da barragem e fazem os custos maiores em PSJ, destacando a heterogeneidade da atividade. A maioria dos pescadores em ambas as comunidades exercem atividades complementares à renda, como o turismo, já que a pesca não é uma atividade rentável. Uma vez que o ecossistema está seriamente fragmentado, os pescadores são altamente vulneráveis à oscilação em custos e lucros, devido à diminuição nas capturas, ocasionada entre outros fatores pelo controle de inundação exercido pelas barragens.
\end{abstract}

Palavras-chave: pesca artesanal, aspectos econômicos, Alto Rio Paraná, planície de inundação, pesca de pequena escala.

\section{Introduction}

Artisanal fishing in Brazil is diffuse and difficult to register but plays a fundamental role in the country's fish production, being responsible for more than $50 \%$ of landings (Cetra and Petrere, 2001). The Upper Paraná River floodplain, which supports local artisanal fishing communities, is a fragmented environment $230 \mathrm{~km}$ long compared to the original ecosystem $(810 \mathrm{~km})$ and is controlled upstream by the Porto Primavera dam and downstream by the Itaipu dam. It reaches up to $20 \mathrm{~km}$ wide in the rainy season (October to January), but the 26 reservoirs upstream (more than $100 \mathrm{Km}^{2}$ ) disrupts fish reproductive cycles, since they control the flood pulse which acts as a cue for the beginning of spawning (from October to January) and for its end, from April to July (Thomaz, 1991; Agostinho and Zalewski, 1996; Vazzoler et al., 1997; Agostinho et al., 2001; Agostinho et al., 2004).

In the past, fishing was on a commercial scale, landing high value species such as Salminus brasiliensis (Cuvier, 1817) and Pseudoplatystoma corruscans (Spix and Agassiz, 1829), but nowadays impoundment of the river affects migration, survival and recruitment of the fish stocks (Agostinho et al., 1992, 1994a). 
Consequently fishing has declined and assumed subsistence characteristics. Despite this, the artisanal fisheries have not been documented and data available refer to the biology of the fish stocks and the environment (Agostinho et al., 1993, 1999, 2001).

This paper examines the financial status of smallscale fishing in the Upper Paraná River floodplain and the variables which determine its profitability, highlighting the needs of the fishing communities and supporting planning and policy actions to maintain the fishing activities and related cultural heritage.

\section{Study Area}

This work was conducted in the Upper Paraná River floodplain (Figure 1), an ecosystem important for the maintenance of fish stock in the Itaipu reservoir downstream (Thomaz, 1991) and for fish reproduction during flooding (Agostinho et al., 2001; 1994a; 1992). Due to the impoundment upstream, actions to protect the fish stocks were created, such as the Decree of the Grande Isle National Park and the EPA (Environmental Protection Area) of Paraná River's Isles and

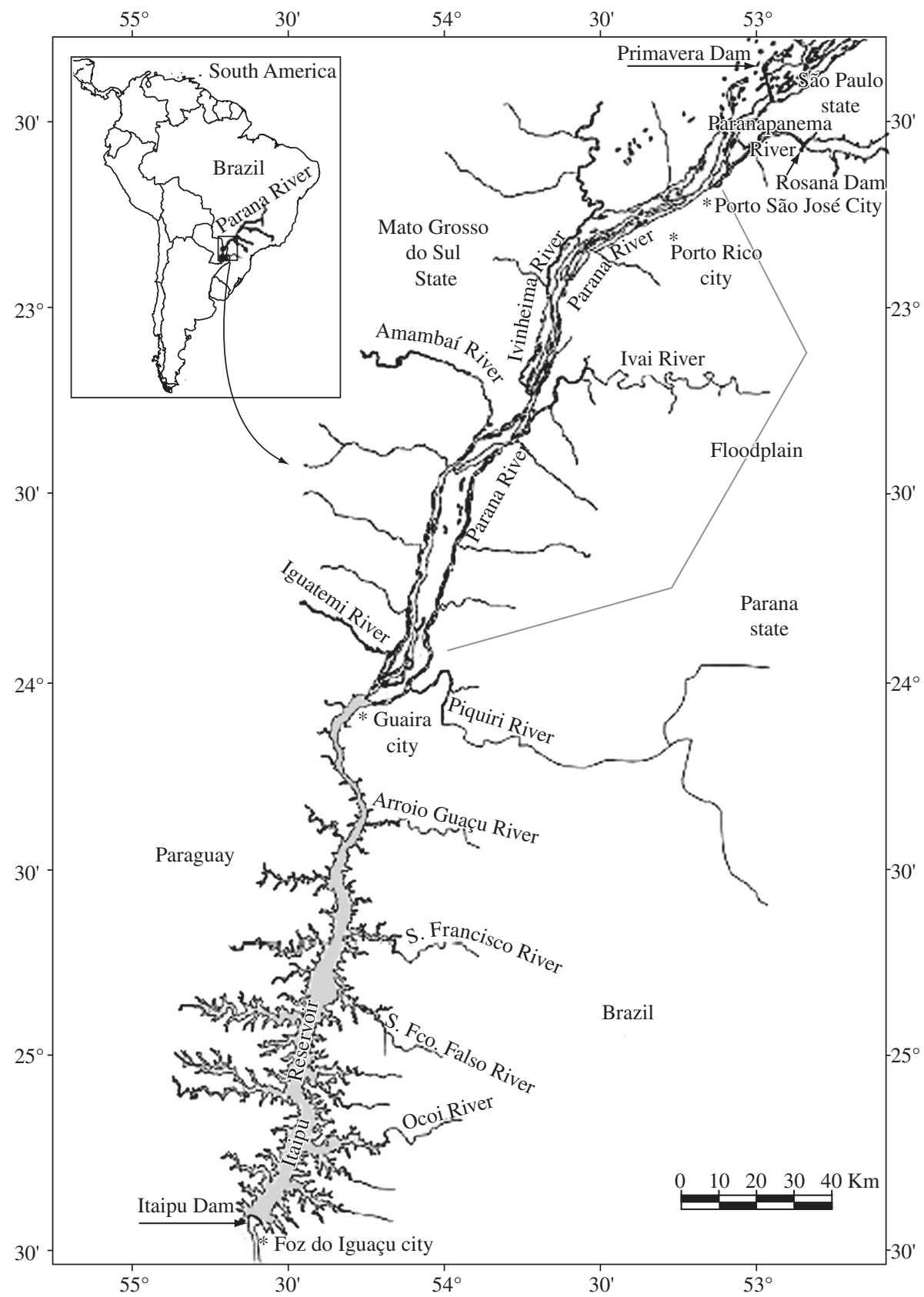

Figure 1. The Upper Paraná River floodplain, Porto Rico and Porto São José cities. 
Floodplains in 1997, the State Park of Rio Ivinheima Floodplains and the enforcement of a Fishing Ban introduced in 1998, (or 'Closed Fishing'), from $1^{\text {st }}$ November until $1^{\text {st }}$ February annually. During this period fishers are permitted to catch just $5 \mathrm{~kg} / \mathrm{fish}$ and those registered in the Fishing Colony (Z-14) receive a salary of U\$ 86.64 (1 US\$ = R \$ 3.20 in April 2003).

Due to its extension, volume $\left(5.0 \times 10^{8} \mathrm{~m}^{3} /\right.$ year through $2.8 \times 10^{6} \mathrm{Km}^{2}$ ) and numerous islands and channels, the Paraná River has an artisanal fishing activity practiced by fishers from Porto Rico (PRI) and Porto São José (PSJ) villages (Figure 1) and also attracts tourists at weekends and holidays for fishing, boating, swimming and relaxing.

Colony Z-14 registers fishers from 23 villages spread throughout the region. In February 2000 there were 800 fishers registered, but only 600 pay the annual tax (US\$ 1.56) for their affiliation, albeit not all of them practice fishing as their main occupation. Nowadays there are as many as 55 fishers in the floodplain, of whom 30 fish in PRI and 25 in PSJ (Mr Francisco Vicente Vieira -Colony Z-14 President, personal communication).

Structure and fishing patterns are distinct, with more gear variability, and consequently richness of species caught, in PSJ. However there is poor social organization and the children have not been taught the fishing tradition (Carvalho, 2004). On the other hand, fishers have deep traditional knowledge about the ecological processes which control ecosystem integrity and fishing dynamics and a recognition concerning the anthropogenic alterations and their consequences for the fish habitats and population (Carvalho, 2002a, b).

\subsection{Survey design and estimative of costs, income and profits}

Interviews were carried out at PRI and PSJ in October 1999, February and April 2000 using a closedended questionnaire that recorded socioeconomic background information (such as age, income, sex, marital state, number of dependents) and fishing related data (catch, income, costs of the activity, complementary occupation, wife's occupation and her income, etc.)

Calculation of costs and income of the fishers were based upon the information supplied by the questionnaire following the formulas from Agostinho et al. (1994b), Okada, et al. (1997) and Ceregato and Petrere (2003).

Once the gear (and its components, such as hooks, lines, nets) were identified, the following variables were estimated: unitary price of the gear $\left(\mathrm{P}_{\mathrm{G}}\right)$ which encompasses gear manufacturing costs; annual depreciation of fishing gear $\left(D_{G}\right)$, that can be determined from unitary price and the fishing gear lifespan $\left(\mathrm{t}_{\mathrm{G}}\right)$ in years $\left(\mathrm{D}_{\mathrm{G}}=\mathrm{P}_{\mathrm{G}} / \mathrm{t}_{\mathrm{G}}\right)$; gear maintenance $\left(\mathrm{M}_{\mathrm{G}}\right)$ corresponded to materials needed to repair gear (lines, hooks, etc).

Thus, costs of the fishing gear $\left(\mathrm{C}_{\mathrm{GEAR}}\right)$ are given by:

$\mathrm{C}_{\mathrm{GEAR}}=\mathrm{D}_{\mathrm{G}}+\mathrm{M}_{\mathrm{G}}$

After the boat type and propulsion system were specified, the following variables could be determined: unitary price of the boat $\left(\mathrm{P}_{\mathrm{B}}\right)$ and propulsion system $\left(\mathrm{P}_{\mathrm{P}}\right)$, as well as the duration in years of the boat and of the propulsion system $\left(t_{B}\right.$ and $t_{P}$, respectively); an annual depreciation of the boat $\left(D_{B}=P_{B} / t_{B}\right)$ and propulsion system $\left(D_{P}=P_{P} / t_{P}\right)$. In all cases it was assumed that depreciation does not vary as a function of maintenance of the boat $\left(\mathrm{M}_{\mathrm{B}}\right)$ and of the propulsion system $\left(\mathrm{M}_{\mathrm{P}}\right)$, informed by fishers. Usually the maintenance of the boat represents $10 \%$ of its unitary cost (Okada et al. 1997).

The costs for the vessel (boat and propulsion system) are:

$\mathrm{C}_{\mathrm{VESSEL}}=\mathrm{D}_{\mathrm{B}}+\mathrm{M}_{\mathrm{B}}+\mathrm{D}_{\mathrm{P}}+\mathrm{M}_{\mathrm{P}}$

A variable $\operatorname{cost}\left(\mathrm{C}_{\mathrm{v}}\right)$ related to fuel consumption (gasoline and oil) of the propulsion system (an average per trip), fish preservation (which varies as a function of the use of ice, refrigerator or freezer) were also estimated. The assistant's wages can be included, if there are fishing partners.

Thus, the cost $(\mathrm{C})$ to the fishers is:

$\mathrm{C}=\mathrm{C}_{\text {GEAR }}+\mathrm{C}_{\text {veSSEL }}+\mathrm{C}_{\mathrm{v}}$

Income was defined by two ways: asking fishers directly (declared income $-\mathrm{I}_{\mathrm{DECL}}$ ) or estimated from their catches. To calculate income it is necessary to know the amount $(\mathrm{kg})$ of species $\mathrm{S}$ caught $\left(\mathrm{K}_{\mathrm{S}}\right)$ and the average sale price per $\mathrm{kg}\left(\mathrm{P}_{\mathrm{S}}\right)$, which are provided by fishers. Thus, they were asked about the catch in the last trip previous or simultaneous to the interview. The income estimated from their catches is given by:

$\mathrm{I}_{\mathrm{EST}}=\Sigma \mathrm{K}_{\mathrm{S}} \times \mathrm{P}_{\mathrm{S}}$

Profit $(\mathrm{P})$ was obtained by subtracting the costs from the income:

$\mathrm{P}=\mathrm{I}_{\mathrm{EST}}-\mathrm{C}$

To identify and quantify variables that determined income generation, a multiple linear regression model was performed. The explanatory variables were: AGE, schooling ( $\mathrm{SCHOOL})$, costs of food acquisition $\left(\mathrm{C}_{\mathrm{FOOD}}\right)$, costs of gear $\left(\mathrm{C}_{\mathrm{GEAR}}\right)$, costs of vessel $\left(\mathrm{C}_{\mathrm{VESSEL}}\right)$, number of days in a week of fish consumption $\left(\mathrm{D}_{\mathrm{FISH}}\right)$, quantity of fish consumed weekly $\left(\mathrm{Q}_{\mathrm{FISH}}\right)$ and years of experience in fishing $\left(\mathrm{Y}_{\mathrm{FISH}}\right)$. Dependent variables tested were income declared by fishers $\left(\mathrm{I}_{\mathrm{DECL}}\right)$, and income estimated from catches $\left(\mathrm{I}_{\mathrm{EST}}\right)$. The categorical variable SCHOOL (schooling) was defined as a dummy variable (Chatterjee and Price, 1991).

\section{Results}

Twenty fishers were interviewed at Porto Rico $(66 \%)$ and at Porto São José (80\%). Men represented $95 \%$ of the sample (only 2 were women).

Depending on the commercial value of the fish, the catch was sold at local markets or used for subsistence purposes. Thus, the mean quantity of fish consumed dai- 
ly was low and of $82.1 \mathrm{~g}$ person $^{-1}$ at PRI (s.d. $\left.= \pm 100\right)$ or of $84.6 \mathrm{~g} \mathrm{x}$ person $^{-1}$ at PSJ (s.d. $= \pm 66.5$ ).

Younger fishers worked at PSJ $(61 \%<30$ years old compared with $20 \%$ at PRI) and the mean age varies from 38 years old at PRI to 34 at PSJ, of which 20 years were dedicated to fishing at PRI and 18 at PSJ. Thirty percent of fishers at PRI and $40 \%$ at PSJ had been practicing fishing for less than 15 years. Half of the fishers in PRI and 44\% in PSJ are illiterate. At PSJ $44 \%$ of fishers were registered in the Fishing Colony Z-14 (annual fee $=$ US\$ 1.56) and $90 \%$ were professionally registered (at IBAMA whose annual tax = US\$3.12); while 95\% of fishers at PRI held both documents.

\subsection{Income estimate in both localities}

Fishing was not an exclusive livelihood for $66 \%$ of fishers at PRI and for half of fishers at PSJ. The most common additional jobs at PRI were bricklayer's assistant $(37 \%)$, tourist guide $(21 \%)$ and guard at summer resort houses (14\%). In PSJ, being a tourist guide was the most frequent second job (34\%), followed by bricklayer's assistant (25\%) and agriculture (17\%).

Just $5 \%$ of wives were involved in fishing in Porto Rico and $20 \%$ in Porto São José, processing fish or catching baits for their husbands. The majority of wives were housewives (61\% at PRI and $47 \%$ at PSJ). Other occupations for the wives were charwomen $(17 \%$ at PRI; $7 \%$ at PSJ) and teachers (11\% at PRI; $13 \%$ at PSJ). Table 1 shows estimated values of fishing income in PRI and PSJ, pointing out the difference among the estimated income and that declared by fishers, which is higher at PSJ than at PRI; their complementary income, which is the same in both villages; the costs of gear, which again is higher at PSJ; and wives earnings which is $30 \%$ higher in PRI.

At PSJ there was also the cost of the ceva (fermented soya and maize grain used to attract some fish spe- cies) and of the 'cevadeira' a local device constructed by them (Carvalho, 2004). This strategy includes a weekly expense of 50 litres of ceva (about $37 \mathrm{~kg}$ ), at a mean cost of US\$ 4.31 resulting in a mean increment of US\$ 17.24/month for each fisher. The fisher also has the expense of US\$ 7.05 to set up the 'cevadeira', which was divided by twelve to spread its cost monthly and estimate the amount of US\$17.82/month as the cost of this tackle and the ceva.

A linear model adjusted by village showed that the significant variable for PRI ( $\left.p=0.002 ; \mathrm{R}^{2}=0.4\right)$ is the $\mathrm{C}_{\text {VESSEL }}(\mathrm{p}=0.002)$ while for PSJ $\left(\mathrm{p}=0.03 ; \mathrm{R}_{2}=0.35\right)$ the significant variables were $\mathrm{C}_{\mathrm{VESSEL}}(\mathrm{p}=0.099)$ and $\mathrm{Q}_{\mathrm{FISH}}(\mathrm{p}=0.013)$. Nevertheless, a complete linear model presented the best fit where villages were included as a dummy variable.

The complete linear model was adjusted empirically, by taking the initial model without interactions, and then discarding one by one the factors or covariates with higher p-values. The optimal model reached using the bestfitted dependent variable (estimated income-ESTIN) is presented below $\left(\mathrm{p}=0.002 ; \mathrm{R}^{2}=0.5\right)$.

$\mathrm{I}_{\mathrm{EST}}=$ constant $-11.293 \mathrm{Q}_{\mathrm{FISH}}+0.08 \mathrm{C}_{\mathrm{VESSEL}}+$ Error (6)

Where: $\mathrm{I}_{\mathrm{EST}}=$ estimated income

Constant $=34.794(\mathrm{p}=0.05)$

$\mathrm{Q}_{\mathrm{FISH}}=$ quantity of fish consumed daily $(\mathrm{p}=0.001)$

$\mathrm{C}_{\mathrm{VESSEL}}=$ costs of vessel (boat and propulsion system) $(\mathrm{p}=0.003)$

\section{Discussion}

At the complete linear model the positive coefficient of $\mathrm{C}_{\mathrm{VESSEL}}$ is a consequence of the investment in fuel needed for fishing longer or further away from the port, while the negative coefficient of $\mathrm{Q}_{\mathrm{FISH}}$ is influenced by the catch, since if a low value catch occurs, the whole

Table 1. Estimated monthly mean (US\$) of cost and income of fishers in Porto Rico and Porto São José in 9 months of open fishing (s.d. = standard deviation; $\mathrm{C}_{\mathrm{VESSEL}}=$ cost of boat plus propulsion system; $\mathrm{C}_{\mathrm{GEAR}}=$ costs of gear;* used just in PSJ, see text for explanation).

\begin{tabular}{lcccc}
\hline \multicolumn{1}{c}{ Estimate } & PRI $(\mathbf{n}=\mathbf{2 0})$ & s.d. & PSJ $(\mathbf{n}=\mathbf{2 0})$ & s.d. \\
\hline Costs of vessel & 27.53 & 11.04 & 25.99 & 15.30 \\
Costs of gear & 20.44 & 13.93 & 41.27 & 41.15 \\
Food costs & 42.97 & 14.26 & 60.24 & 24.15 \\
Ceva + cevadeira cost* & - & - & 17.82 & 7.83 \\
Total Costs & 90.94 & 39.23 & 145.32 & 88.43 \\
Declared income $-I_{\text {DECL }}$ & 38.90 & 28.95 & 37.56 & 17.04 \\
Estimated income-I EST $_{\text {DECL }}-I_{\text {EST }}$ & 27.70 & 22.28 & 12.63 & 13.84 \\
Wives income & 11.20 & - & 24.93 & - \\
Complementary income & 42.23 & 18.90 & 32.29 & 26.25 \\
Total income & 34.68 & 31.44 & 35.27 & 47.65 \\
\end{tabular}


fish is taken home for the family to consume, whereas if the fish caught has high commercial value, the whole catch will be traded (to buy other items such as beef) increasing the final revenue.

This low fish consumption by fishers could influence the subsistence nature of the activity, especially when compared to Amazon River communities of 550 g/capita ${ }^{-1}$ per day (Batista et al., 1998; Freitas and Batista 1999). Moreover, curiously some fishers declared they do not appreciate fish and eat it just once a month, so fish is not an important component of the diet, as was found by Castro and Begossi (1995) for fishers on the Grande River (Minas Gerais).

Although high value fish exits into floodplain (Salminus brasiliensis: US\$ $1.55 \mathrm{~kg}^{-1}$ Pseudoplatystoma corruscans: US\$1.40 $\mathrm{kg}^{-1}$ ), the mean revenue estimated was low and close to or less than the costs. The declared income is higher than the income estimated by their catches probably because they are unable to control their earnings, especially due to the declining and variable catches and because of a bias from the minimum wage value in Brazil (US\$ 37.50) which is the same they receive during the three months of the Fishing Ban.

Even if the income was that was declared (Table 1), it would be only half of the estimated income for fishers at the Itaipu reservoir [US\$ 82.75 to 124.13 according to Agostinho et al. (1999)] which is probably influenced by stability in reproductive and feeding areas at the reservoir (contrasting with the floodplain susceptibility to regularization upstream) and by the formal fishing support policies and surveys carried out by the reservoir administrator, the Itaipu Binacional.

Since water related uses are multiple and intense in the floodplain (fishing uses, domestic uses, power generation, recreational activities, domestic discharges, conservation of protected areas), its interaction can result in multi-use conflict. Indeed, although direct conflict between artisanal fishers and recreational fishers was not registered, conflicts were declared just in relation to the fishing inspectors. On holidays and weekends artisanal fishers prefer not to fish to avoid conflict and to make money as sport fishers' guides. Future fish trips, however, are endangered by disputes with fishing inspectors which remove artisanal fishers' gear, especially long lines in which recreational spinning reels could become entangled. Because of these difficulties, artisanal fishers whose gear was confiscated are abandoning the activity or substituting temporary labor that is arising with tourism. This contributes to the artisanal fishing disrepute that has been reported by Petrere (1989) in Brazil and some parts of the world.

Hence, reports of aversion to fiscalization such as occurs in the Danube Delta, in Africa (Boja and Popescu, 2000), violence against fishers during fishing management such as in Indonesia (Bailey and Zerner, 1992), and of the fragile coexistence between fishers and fishing control agencies (Palmer, 1991; Sinclair, 1990) are also common in the Upper Paraná River floodplain. Thus fish- ing in the Upper Paraná River floodplain is in the same situation as artisanal fishing around the country, with low earnings due to environmental alterations and to policies favorable to sport fishing and tourism which do not value or protect the local fishing culture.

Nowadays, floodplain fishers are financially vulnerable to the high deviation in costs and income due to the heterogeneity of the activity and oscillation in catches without the possibility of earnings accumulation. Hence the wife's income is extremelly important to the family sustenance, since it provides for the basic food supply. Since the fishing in PSJ is close to Porto Primavera and Rosana dams, there is more variability in gear used (including the 'cevadeira'/'ceva') and species exploited (Carvalho, 2004) increasing costs and oscillation in catches. A similar poverty situation was observed by Franco de Camargo and Petrere (2001) for fishers of the São Francisco River (Minas Gerais, Brazil).

In the Upper Paraná River floodplain, fishing cannot alleviate poverty, since its profits are low or nonexistent. Rather than representing a 'last resort activity' (Béné, 2003), it represents a rescue of dignity due to its professional importance to fishers and a new perspective for initiates in tourism activities. From this standpoint this small-scale fishing has an important social character and great potential for local development.

Throughout the world, but especially in Asia and Africa, small-scale fishing is referred to and characterized as an activity vulnerable to poverty. Small-scale fishing in developing countries is also characterized by little or no representation of user-groups (fishers) in the formulation and implementation of the fishing management policies (Hollup, 2000). In New Zealand, for instance, as many as 3,000 fishers, mostly small-scale fishers, have exited fishing since the establishment of a quota management system in 1986. Thus the management decision, which should have increased biological and economic status, had an undesired effect (Stewart et al., 2006).

In Brazil, small-scale fishing is reported as a source of food, income and employment, usually with low revenue and deprived social status (Batista et al., 1998; Freitas and Batista, 1999; Almeida et al., 2001; Franco de Camargo and Petrere, 2001; Ceregato and Petrere, 2003).

Recently Parente et al. (2005) adjusted a development index to estimate social, economic and politicalinstitutional indicators for catfish fishing communities spread along the Amazon-Solimões River channel. They confirmed deprivation in the activity as a result of multidimensional factors which include the absence of organizational structure in the social and political-institutional dimensions, rather than an exclusive biological (overexploitation) or economic (low income) factor.

Despite the two pillars of the old paradigm about fishing quoted by Béné (2003) "poor because fishermen" and "fishermen because poor", and in spite of the fact that overexploitation does cause impoverishment, with 
any evaluation of social and institutional mechanisms (including physical isolation, the lack of political voice, low social status and health) must be taken into account, because they play an important role in this activity which is constituted by fishing, the fish and the fishers.

Artisanal fishers have professional abilities in boating and fishing, therefore they have natural qualification as tourist guides. Thus a local policy to provide training towards tourism and hotel operators' demands could be offered at the Fishing Colony, to improve their performance and assure professional assistance to tourists. Also social policies from Federal or local governments such as educational and health assistance programs could be implemented.

According to biosphere reserves from MAB/ UNESCO, Agostinho et al. (2004) suggested the establishment of a permanent floodplain reserve constituted by concentric regions (at least two) with decreased restriction of use in order to improve recruitment performance. Just as important as the floodplain reserve, is the maintenance of flooding. So a managed flood by a formal agreement among hydroelectric concessionaires upstream and their rationalized operation of water discharge during the flood period could permit flooding and the access to fish breeding and nursery areas. This action could preserve stock, artisanal and recreational fishing, and will be helpful to the Fishing Ban period that has no effect on all species without the occurrence of flooding on floodplain areas.

These actions could guarantee ecosystem integrity by maintenance of migration and reproduction, incrementing fish recruitment and consequently local fishing. As a result, small-scale fishing could subsist and increase profits, propitiating a better social well-being for fisher's communities.

Socio-institutional priorities for the fishing communities in the Upper Paraná River floodplain are: 1) training programmes as sport fishing guides to enable this parallel activity that depends on traditional knowledge; and 2) a literacy programme to promote organization of the activity and the legality of the fishers; 3 . training in how to control and understand their costs and earnings; and 4. municipal support for the Fishing Colony Z-14 in order to legitimate fishing as a social and cultural tradition of this last lotic stretch in the Upper Paraná River floodplain.

\section{References}

AGOSTINHO, AA., JULIO, HF., and BORGHETTI, JR., 1992. Considerações sobre os impactos dos represamentos na ictiofauna e medidas para sua atenuação. Um estudo de caso: reservatório de Itaipu. Revista Unimar, vol. 14, suppl., p. 89-107.

AGOSTINHO, AA., VAZZOLER, AE., GOMES, LC., and OKADA, EK., 1993. Estratificación espacial y comportamiento de Prochilodus scrofa en distintas fases del ciclo de vida en la planicie de inundación del alto Rio Paraná y embalse de Itaipu,
Paraná, Brasil. Revista de Hydrobiogia. Tropical, vol. 26, no. 1, p. 79-90.

AGOSTINHO, AA., JUliO, JR. HE., and PETRERE, M., 1994a. Itaipu Reservoir (Brazil): impacts of impoundment on the fish fauna and fisheries. In COWX, IG. (ed.) Rehabilitation of Freshwater Fisheries. Oxford Fishing New Books.Blackwell Sciences, p. 171-184.

AGOSTINHO, AA., OKADA, EK. and GREGORIS, J., 1994b. Características econômicas e socias das atividades pesqueiras no reservatório de Itaipu. In Simpósio regional sobre manejo de la pesca en embalses en américa Latina. FAO/COPESCAL, Havana, 100 p. (Publicaciones Técnicas).

AGOSTINHO, AA. and ZALEWSKI, M., 1996. A planície alagável do alto rio Paraná: importância e preservação. Editora da Universidade Estadual de Maringá, 100 p.

AGOSTINHO AA., AMBRÓSIO, AM., FERREIRA, VS, OLIVEIRA, EF., OKADA, EK., and SUZUKI, HI., 1999. Reservatório de Itaipu - aspectos biológicos e socioeconômicos da pesca. Relatório anual 1997/98, UEM/Nupelia, Maringá/ Paraná, 237 p.

AGOSTINHO, AA., GOMES, LC., and ZALEWSKI, M., 2001. The importance of floodplain for the dynamics of fish communities of the Upper Paraná river. Ecohydrology and Hydrobiology, vol. 1, no. 1-2, p. 209-217.

AGOSTINHO, AA., THOMAZ, SM. and GOMES, LC., 2004. Threats for biodiversity in the floodplain of the Upper Paraná River: effects of hydrological regulation by dams. Ecohydrology and Hydrobiology, vol. 4, no. 3, p. 267-280.

ALMEIDA, OT., McGRATH, DG. and RUFFINO, ML., 2001. The commercial of the lower Amazon:an economic analysis. Fisheries Management and Ecology, vol. 8, p. 253-269.

BAILEY, C., and ZERNER, C. 1992, Community-based fisheries management institutions in Indonésia. MAST Maritime Anthropological Studies, vol. 5, no. 1, p. 1-17.

BATISTA, VS., INHAMUNS, AJ., FREITAS, CEC., and FREIRE-BRASIL, D., 1998. Characterization of the fishery in river communities in the Low-Solimões/High Amazon region. Fisheries management and Ecology, vol. 5, no. 5, 419-435.

BÉNÉ, C., 2003. Contribution of small-scale fisheries to rural livelihoods in a water multi-use context (with a particular emphasis on the role of fishing as "last resort activity" for the poor). FAO Advisory Committee on Fisheries Research. Working Party on Small-Scale Fisheries. Technical Report. Bangkok, Thailand.

BOJA, V., and POPESCU, I., 2000. Social ecology in the Danube Delta: theory and practice. Lakes and Reservoir, vol. 5, no. 2, p. 125-131.

CARVALHO, AR., 2002a, Conhecimento ecológico tradicional no fragmento da planície de inundação do alto rio Paraná: percepção ecológicas dos pescadores. Acta Scientiarum, vol. 24, no. 2, p. 573-580.

-, 2002b, Conhecimento ecológico no 'varjão' do alto rio Paraná: alterações antropogêniacs expressas na linguagem dos pescadores. Acta Scientiarum, vol. 24, no. 2, p. 581-589.

-, 2004, Social and structural aspects of artisanal fishing in the Upper Paraná River floodplain (Brazil). Boletim do Instituto de Pesca, vol. 30, no. 1, p. 35-42. 
CASTRO, F., and BEGOSSI, A., 1995. Ecology of fishing on the Grande river (Brazil): technology and territorial rights. Fisheries Research, vol. 23, p. 361-373.

CEREGATO, SA. and PETRERE, M., 2003. Financial comparisons of the artisanal fisheries in Urubupungá Complex in the Middle Paraná River (Brazil). Brazilian Journal of Biology, vol. 63, no. 4, p. 673-682.

CETRA, M. and PETRERE, M., 2001. Small-scale fisheries in the middle river Tocantins, Imperatriz (MA), Brazil. Fisheries Management and Ecology, vol. 8, no. 2, p. 153-162.

CHATTERJEE, S. and PRICE, B., 1991. Regression analysis by example. 2 ed. John Wiley and Sons, New York, 278p.

FRANCO DE CAMARGO, SA., and PETRERE, M., 2001. Social and financial aspects of artisanal fisheries of Middle São Francisco River/MG, Brazil. Fisheries management and Ecology, vol. 8, p. 163-71.

FREITAS, CEC., and BATISTA, VS., 1999. A pesca e as populações ribeirinhas da Amazônia Central. Brazilian Journal of Ecology, vol. 3, no. 2, p. 31-39.

HOLLUP, O., 2000. Structural and sociocultural constraints for user-group participation in fisheries management in Mauritius. Marine Policy, vol. 24, p. 407-421.

OKADA, EK., GREGORIS, J., AGOSTINHO, AA. and GOMES, LC., 1997. Diagnóstico da pesca profissional em dois reservatórios do Rio Iguaçu. In AGOSTINHO, AA. and GOMES, LC. Reservatório de Segredo: bases ecológicas para o manejo, Editora da Universidade de Maringá, p. 293-318.
PALMER, CT., 1991. The life and Death of a small-scale fishery: surf clam dredging in southern Maine. MAST - Maritime Anthropological Studies, vol. 4, no. 1, p. 56-72.

PARENTE, VM., VIEIRA, EF., CARVALHO, AR. and FABRÉ, NN., 2005. A pesca e a economia da pesca de bagres no eixo Solimões-Amazon River, In FABRÉ, NN., BARTHEM, RB. (org.). O manejo da pesca dos grandes bagres migradores: piramutaba e dourada no eixo Solimões-Amazonas. Coleção de Documentos Técnicos: Estudos Estratégicos. Ibama, ProVárzea. Manaus, p. 49-65.

PETRERE, M. JR., 1989. River Fisheries in Brazil: a review. Regulated rivers: research and management, vol. 4, p. 1-16.

SINCLAIR, PR., 1990. Fisheries management and problems of social justice. MAST-Maritime Anthropological Studies, vol. 3, no. 1 , p. 30-47.

STEWART., J., WALSHEB, K. and MOODIEA, B., 2006. The demise of the small fisher? A profile of exiters from the New Zealand fishery. Marine Policy, vol. 30, p. 328-340.

THOMAZ, SM., 1991. Influência do regime hidrológico (pulsos) sobre algumas variáveis limnológicas de diferentes ambientes aquáticos da planície de inundação do alto rio Paraná, MS, Brasil. São Carlos: UFSCAR. 244 p. (Dissertação de mestrado) - Universidade Federal de São Carlos.

VAZZOLER, AE., LIZAMA, MLAP. and INADA, P., 1997. Influências ambientais sobre a sazonalidade reprodutiva. In VAZZOLER, AEAM., AGOSTINHO, AA., HAHN, NS. (eds.). A planície de inundação do alto Rio Paraná. Maringá: EDUEM. p. 267-280. 
